\title{
Characteristics of inhibition of infectious pancreatic necrosis virus (IPNV) by normal rainbow trout Oncorhynchus mykiss serum
}

\author{
Kyoung C. Park ${ }^{1,2, *}$, Paul W. Reno ${ }^{1}$ \\ ${ }^{1}$ Department of Microbiology and Coastal Oregon Marine Experimental Station, Hatfield Marine Science Center, \\ Oregon State University, 2030 SE Marine Science Drive, Newport, Oregon 97365, USA \\ ${ }^{2}$ Present address: Institute for Marine Biosciences, National Research Council Canada, 1411 Oxford Street, Halifax, \\ Nova Scotia B3H 3Z1, Canada
}

\begin{abstract}
We studied the characteristics of rainbow trout serum (RTS) inhibitory activity against infectious pancreatic necrosis virus (IPNV). Serum inhibition was related to the serum source and host cell in which the virus had been propagated. IPNV was more efficiently inhibited by RTS in salmonid cell lines than in non-salmonid cell lines, with inhibition highest in rainbow trout gonad (RTG)-2 cells. The RTS sensitivity of the virus was modified by the cell line through which the virus passed, with multiple passages through Chinook salmon embryo (CHSE)-214 cells producing a virus that was less sensitive to RTS. The RTS inhibition level was dependent on cell density: at a cell density of $\leq 2 \times 10^{5}$ cells $\mathrm{ml}^{-1}$, inhibition was insignificant (tissue culture infective dose $50 \%=10^{-1.1} \mathrm{TCID}_{50} \mathrm{ml}^{-1}$ reduction); however, above a density of $3 \times 10^{5}$ cells ml ${ }^{-1}$, the inhibition level was very high $\left(\geq 10^{-6.3} \mathrm{TCID}_{50} \mathrm{ml}^{-1} \mathrm{re}-\right.$ duction). The salmonid sera tested showed high inhibition, except for brook trout serum (BTS), while non-salmonid sera did not inhibit IPNV, replication on RTG-2 cells. Pretreatment of cultured cells with RTS prior to exposure did not affect inhibition of IPNV and thus did not mask a viral receptor. The RTS inhibition level was dependent on the time of serum addition, with inhibition being maintained for at least $16 \mathrm{~h}$ postinfection. Pretreatment of IPNV revealed that the virus is directly inhibited by RTS, and more strongly so when RTS is present during viral replication.
\end{abstract}

KEY WORDS: Infectious pancreatic necrosis - IPNV · Rainbow trout serum · Inhibition

\section{INTRODUCTION}

The infectious pancreatic necrosis virus (IPNV), (Birnaviridae) causes highly destructive diseases in salmonid fishes, and has also been isolated from many non-salmonid species (Reno 1999). An IPNV inhibitor, designated '6S inhibitor' by earlier authors (e.g. Dorson \& de Kinkelin 1974, Ögüt 1995), has been reported in rainbow trout serum (RTS) collected from individuals fish with no previous exposure to IPNV (Dorson \& de Kinkelin 1974). Dorson \& de Kinkelin (1974) reported that the serum inhibitor had a sedimentation coefficient (ultracentrifugation) of approximately $6 \mathrm{~S}$ and thus differs from the fish antibody tetrameric IgM, which has a sedimentation coefficient of 14-16S. Since the first report of IPNV inhibition by RTS, many reports have been published on this topic. However, most of these have been restricted to information about the RTS sensitivity of IPNV or the relationship between the RTS sensitivity of IPNV and its virulence (VestergardJörgensen 1973, Dorson \& de Kinkelin 1974, Hill \& Dixon 1977, Dorson et al. 1978, Ögüt 1995). Not all virus isolates tested were inhibited by RTS, and the inhibition was not dependent on any specific IPNV serotype (Macdonald \& Gower 1981, Okamoto et al. 1983a, Ögüt 1995).

It has often been reported that cell culture-adapted virus strains are more susceptible to RTS than wild 
virus types (Dorson et al. 1975, 1978, Hill \& Dixon 1977), and also that RTS sensitivity is correlated with the virulence of IPNV and is modified by cell passage (Hill \& Dixon 1977, Hill 1982, Ögüt 1995). There are few reports on the mechanism of RTS inhibition or characteristics related to RTS inhibitory activity. Kelly \& Nielson (1985) observed that viral adsorption to cells was somewhat inhibited in the presence of RTS. Hill \& Dixon (1977) reported that the RTS sensitivity of IPNV developed sooner after multiple viral passages through the epithelioma papillosum cyprinid (EPC) line than after passages through the RTG-2 or bluegill fry (BF) cell lines. Although it was not indicated that RTS inhibition (' $6 \mathrm{~S}^{\prime}$ ) was related to cellular induction by serum molecules such as interferon, some reports have shown that IPNV is inhibited by serum molecules such as interferon (de Kinkelin \& Dorson 1973, de Kinkelin \& Le Berre 1974, Dorson et al. 1992).

In this paper, we described the inhibition characteristics of RTS inhibitor of IPNV under several experimental conditions.

\section{MATERIALS AND METHODS}

Serum preparation. Fishes were obtained either from wild or hatchery sources. Details of used as serum sources are given in Table 1. Rainbow trout Oncorhynchus mykiss were obtained from the Oregon Department of Fish and Wildlife hatchery at Alsea; no IPNV has been detected at this facility for more than 25 yr. Blood samples were collected by caudal vein puncture and pooled from approximately 20 adult fish weighing approximately $600 \mathrm{~g}$ each. The blood was allowed to clot at $5^{\circ} \mathrm{C}$ overnight and centrifuged at $1000 \times g$ for $20 \mathrm{~min}$. The serum from other species was prepared in the same way. The serum was collected and portions were dispensed into $1 \mathrm{ml}$ aliquots and stored in liquid nitrogen until use (Kelly \& Nielsen 1985).

Virus. The IPNV isolate used in most of our experiments was the archetype of Serotype $A_{9}$, Jasper. This virus was isolated from diseased brook trout Salvelinus fontinalis in Maligne River Hatchery, Alberta, Canada (Yamamoto 1974), and was obtained from Dr. B. Nicholson, University of Maine, and Orono, Maine, and originally donated to him by Barry Hill (DAFF, Weymouth, UK). The virus has been passaged for years in our laboratory. The other IPNV isolate used was a member of Serotype $A_{2}(\mathrm{Sp})$, designated 'Thailand'. This virus was originally isolated from diseased snakehead fish Ophicephalus striatus in Thailand (Wattanavijarn et al. 1988). The isolate was obtained from the laboratory of Dr. Wattanavijarn.

Serum inhibition of virus in vitro. The RTG- 2 cell line (Wolf \& Quimby 1962) and other cell lines used for each experiment were propagated in 24-well plates as described by Caswell-Reno et al. (1989) (Table 2). We prepared 3 replicate wells for each condition. In this experiment, 3 types of media were used: Eagle's minimum essential medium (MEM) without serum (MEM-0), MEM + 10\% fetal bovine serum (MEM-10) and MEM + $10 \%$ fetal bovine serum + 1\%RTS (MEMRTS). Virus was diluted with MEM-10 or MEM-RTS to give a final virus concentration of $10^{4} \mathrm{TCID}_{50} \mathrm{ml}^{-1}$. We added $300 \mu \mathrm{l}$ of diluted virus to a drained, confluent monolayer of cells in each well and incubated these at room temperature for $2 \mathrm{~h}$. After incubation the inoculated monolayers were washed 3 times with MEM-0, and $1 \mathrm{ml}$ of either MEM-10 or MEM-RTS was added. Uninoculated controls were treated with either medium, as appropriate. Cells were incubated at $18^{\circ} \mathrm{C}$ for $7 \mathrm{~d}$ in an incubator with a $5 \% \mathrm{CO}_{2}$ supply. The cytopathic effect (CPE) level was monitored daily and scaled on an ordinal scale from 0 (no CPE) to 4 (complete CPE). On the seventh day of exposure, cell culture supernatant from each well was harvested, pooled with its replicated wells, and held in liquid nitrogen until titrated.

Virus titration. The end-point dilution method described by Caswell-Reno et al. (1986) was used for virus titration. Virus samples were serially diluted 10fold with MEM-0 and then $100 \mu$ l of diluted virus were

Table 1. Sources and characteristics of 7 fish sera used to study inhibition of infectious pancreatic necrosis virus (IPNV). W, H: fish obtained from wild or hatchery individuals, respectively; Wt: mean weight of fish from which serum was obtained; N: number of individuals used for serum pool

\begin{tabular}{|c|c|c|c|c|}
\hline Serum & Species & $\mathrm{W} / \mathrm{H}$ & Wt (kg) & $\mathrm{N}$ \\
\hline RTS (rainbow trout serum) & Oncorhynchus mykiss & $\mathrm{H}$ & 0.6 & 20 \\
\hline COS (coho salmon serum) & Oncorhynchus kisutch & $\mathrm{H}$ & 2.0 & 10 \\
\hline CHS (chinook salmon serum) & Oncorhynchus tshawytscha & $\mathrm{H}$ & 2.0 & 10 \\
\hline BTS (brook trout serum) & Salvelinus fontinalis & $\mathrm{H}$ & 0.5 & 30 \\
\hline FLS (starry flounder serum) & Platichthys stellatus & W & 2.0 & 1 \\
\hline SAS (sablefish serum) & Anoplopoma fimbria & $\mathrm{W}$ & 5.0 & 1 \\
\hline HES (Pacific herring serum) & Clupea harengus pallasi & $\mathrm{W}$ & 0.1 & 30 \\
\hline
\end{tabular}


Table 2. Characteristics of 13 continuous teleost cell lines (9 salmonid cell lines and 4 non-salmonid cell lines) tested for their ability to enhance virus inhibition of RTS inhibitor. Cell morph.: cell morphology; E: epithelioid; F: fibro blastic

\begin{tabular}{|lcccc|}
\hline Cell line & Tissue source & Species of origin & Cell morph. & Source \\
\hline CHH-1 & Chum heart-1 & Oncorhynchus keta & E & Lannan et al. (1984) \\
CHSE-114 & Chinook salmon embryo & Oncorhynchus tshawytscha & E & Lannan et al. (1984) \\
CHSE-214 & Chinook salmon embryo & Oncorhynchus tshawytscha & E & Lannan et al. (1984) \\
KO-6 & Kokanee ovary & Oncorhynchus nerka & E & Lannan et al. (1984) \\
RTG-2 & Rainbow trout gonad & Oncorhynchus mykiss & F & Wolf \& Quimby (1962) \\
RTH-149 & Rainbow trout hepatoma & Oncorhynchus mykiss & E & Lannan et al. (1984) \\
SSE-5 & Sockeye salmon embryo & Oncorhynchus nerka & E & Lannan et al. (1984) \\
STE-137 & Steelhead trout embryo & Oncorhynchus nerka & E & Lannan et al. (1984) \\
YNK & Yamame kidney & Oncorhynchus masou & F & Watanabe et al. (1978) \\
BB & Brown bullhead & Ictalurus nebulosus & E & Wolf \& Quimby (1969) \\
BF-2 & Bluegill sunfish & Lepomis machrochirus & F & Wolf \& Quimby (1966, 1969) \\
CCO & Channel catfish ovary & Ictalurus punctatus & F & Bowser (1976) \\
PHE-184 & Pacific herring embryo & Clupea harengus pallasi & E & C. N. Lannan \& R. B. Olson (unpubl. data) \\
\end{tabular}

added to each of 4 wells of a 96-well plate containing monolayers of CHSE-214 cells (Lannan et al. 1984). After incubation at $18^{\circ} \mathrm{C}$ for $7 \mathrm{~d}$, wells showing CPE were counted to determine the $50 \%$ tissue culture infectious dose $\left(\right.$ TCID $_{50} \mathrm{ml}^{-1}$ ) as defined by Spearman (1908).

Effect of RTS pretreatment of cells. To determine if treatment of RTG-2 cells with RTS results in viral inhibition similar to treatment with interferon, unexposed cells were treated with MEM-RTS at various concentrations for $24 \mathrm{~h}$ followed by thorough washing of the cells prior to infection with virus. A modification of the method described by De Sena \& Rio (1975) was employed. Rainbow trout serum was diluted in MEM10 at the ratios of 5.0, 2.5, 1.8, and 1.0\%. Each diluted serum sample was incubated in 3 replicate wells in 24well plates containing confluent RTG-2 cells (approx. $3 \times 10^{5}$ cells well ${ }^{-1}$ ). Control wells were pretreated with MEM-10. After $24 \mathrm{~h}$ treatment, the wells were washed 3 times with MEM-0 and infected with $300 \mu \mathrm{l}$ of IPNVJasper at a concentration of $10^{4} \mathrm{TCID}_{50} \mathrm{ml}^{-1}$. After $2 \mathrm{~h}$ incubation, the inoculated monolayers were washed 3 times with MEM-0 and then $1 \mathrm{ml}$ of MEM-10 was added to each well. After $7 \mathrm{~d}$ incubation, virus titer was determined as described above.

Groups of triplicate wells containing RTG-2 cells were treated with MEM-RTS or MEM-10 (controls) for $2 \mathrm{~h}$. After treatment, the cells were washed $0,1,3,5$ and 10 times each with MEM-0 and then exposed to $300 \mu$ of IPNV-Jasper containing $10^{4} \mathrm{TCID}_{50} \mathrm{ml}^{-1}$ for $2 \mathrm{~h}$. Following virus exposure, the cells were washed 3 times with MEM-0, and then $1 \mathrm{ml}$ of MEM-10 was added to each well. Cells were subsequently incubated for $7 \mathrm{~d}$ and titrated following the methods described above.

Effect of time of serum addition on inhibition. RTG2 cells were grown with MEM-10 in 24-well plates (approx. $3 \times 10^{5}$ cells well $^{-1}$ ) and exposed to $300 \mu \mathrm{l}$ of $10^{4} \mathrm{TCID}_{50} \mathrm{ml}^{-1}$ IPNV-Jasper in either MEM-10 or MEM-RTS for $2 \mathrm{~h}$ at $18^{\circ} \mathrm{C}$ as described above. For this experiment, RTS was added to 3 wells of RTG- 2 cells at various times pre- and post-exposure to IPNV. At Time 0 , virus and MEM-RTS or MEM-10 were added to cells concurrently. After $2 \mathrm{~h}$ incubation with virus, all wells were washed 3 times with MEM-0 and then wells were incubated with MEM-10 or MEM-RTS as appropriate. In Time A groups, virus was exposed to MEM-RTS or MEM-10 before cell infection at different time intervals. In Time B groups, cells were incubated with MEM-10 until the specific time of MEM-RTS addition. On the 7 th day, virus titers and the levels of CPE (determined visually) were determined from each well of MEM-RTS or MEM-10.

Effect of $2 \mathrm{~h}$ pre-infection treatment with RTS only vs. pre-infection plus 7 d incubation with RTS. We treated $500 \mu \mathrm{l}$ of Thailand IPNV isolate at a concentration of $10^{9} \mathrm{TCID}_{50} \mathrm{ml}^{-1}$ for $2 \mathrm{~h}$ with an addition of either $4.5 \mathrm{ml}$ MEM-RTS or $4.5 \mathrm{ml}$ MEM-10 (control). The virus incubated in MEM-RTS was diluted with MEMRTS or with MEM-10 to a virus concentration of $10^{9}$ to $10^{0} \mathrm{TCID}_{50} \mathrm{ml}^{-1}$ while that incubated in MEM-10 was diluted with MEM-10 to a concentration of $10^{9}$ to $10^{0} \mathrm{TCID}_{50} \mathrm{ml}^{-1}$. Since the end-point of RTS inhibition in a preliminary experiment was at RTS 1:800 dilution, a further $10^{-1}$ dilution with MEM-10 of virus (originally incubated in 1:100 RTS) was conducted to produce a concentration less than the lowest inhibitory concentration of RTS. Thus, if the virus were affected by RTS, the effect would be a result of the initial $2 \mathrm{~h}$ pre-treatment rather than ot the residual RTS in the incubation medium. We added $100 \mu \mathrm{l}$ of each viral concentration, ranging from $10^{0}$ to $10^{8} \mathrm{TCID}_{50} \mathrm{ml}^{-1}$, from each condition to each well of 96-well plates prepared with CHSE-214 cell monolayer. After incubation at $18^{\circ} \mathrm{C}$ for 
$7 \mathrm{~d}$, the $50 \%$ tissue culture infectious dose was compared between dilution plates.

RTS and CHS inhibition of IPNV in RTG-2 and CHSE-214 cells. To determine if homologous cell line and serum pairings affected inhibitory activity, both chinook salmon and RTS samples and cell lines were tested. The 2 cell lines RTG- 2 and CHSE-214 were propagated in 24-well plates as described above. IPNV-Jasper was diluted with MEM-10 (control) or MEM-RTS or MEM $+10 \%$ fetal bovine serum $+1 \%$ Chinook salmon serum (MEM-CHS) to a final virus concentration of $10^{4} \mathrm{TCID}_{50} \mathrm{ml}^{-1}$. We added $300 \mu \mathrm{l}$ samples of each diluted virus in MEM-10, MEM-RTS or MEM-CHS to both RTG-2 and CHSE-214 cells. After $2 \mathrm{~h}$ incubation, the inoculated monolayers were washed 3 times with MEM- 0 and then $1 \mathrm{ml}$ of MEM10, MEM-RTS or MEM-CHS was added. Cells were incubated for $7 \mathrm{~d}$ and the virus titer was then determined.

Sensitivity of virus to RTS following passage through RTG-2 or CHSE-214 cells. To determine if passage through homologous or heterologous cells affected inhibitory activity, IPNV-Thailand was passed 5 times through CHSE-214 or RTG-2 cells. Viral RTS sensitivity was compared after 1 or 5 passages in each of the cell lines. To check for any alteration in RTS sensitivity, we determined viral inactivation after $2 \mathrm{~h}$ incubation with MEM-RTS. We incubated $100 \mu \mathrm{l}$ samples of Passage 1 and Passage 5 virus originating from either CHSE-214 or RTG-2 at a concentration of $10^{8} \mathrm{TCID}_{50} \mathrm{ml}^{-1}$ with $900 \mu \mathrm{l}$ of MEM-RTS or MEM-10 for $2 \mathrm{~h}$. Each passage from the 2 cell lines was serially diluted with MEM-10 to a concentration of $10^{0} \mathrm{TCID}_{50}$ $\mathrm{ml}^{-1}$. We inoculated $100 \mu \mathrm{l}$ of each viral dilution from MEM-RTS and MEM-10 origin into 96 replicate wells of a microtiter plate containing CHSE-214 cells instead of RTG-2 cells; 7 d later, the virus titer was compared between MEM-RTS and MEM-10.

Effect of cell density on RTS inhibition. RTG-2 cells in a $75 \mathrm{~cm}^{2}$ flask were trypsinized and then serially diluted in 2-fold steps to $2^{-5}$ with MEM-10. Diluted cells were seeded into 24 -well microtiter plates (4 replicates for each cell concentration), and $4 \mathrm{~d}$ later, the cells from 1 of 4 wells of each cell dilution were counted in a hemocytometer after trypsinization. After determination of the number of cell per well, virus inhibition tests were conducted on the remaining replicate wells using the IPNV-Jasper isolate, following the methods used in the serum inhibition tests.

RTS inhibition of salmonid and non-salmonid cell lines. We tested 13 continuous teleost cell lines for their ability to enhance the inhibition of IPNV by RTS (Table 1). The cells originated from marine and freshwater fishes as well as salmonid and non-salmonid fishes, and both epithelial and fibroblastoid cell types were represented. Each cell line was propagated in 24 -well plates. We tested 3 replicate wells for each cell line when cell lines were $100 \%$ confluent. The inhibition test for RTS was the same as that for RTG2 cells.

Interspecific range of serum inhibitory activity directed against IPNV. Sera collected from 7 species of teleost fishes were used to determine their species' ability to inhibit IPNV. We selected 2 isolates known to be highly sensitive, Thailand ( $A_{2}$, Sp serotype), or midsensitive, Jasper $\left(A_{9}\right.$, Jasper serotype) to inhibition by RTS. Sera were collected from the species listed in Table 1, prepared as for RTS, and held in liquid nitrogen until use. All sera were diluted to 1:100 in MEM10. The inhibition test was carried out on RTG-2 cells as in an earlier subsection.

Statistical analysis. Analysis of variance was made for all data on virus activity after log-transformation. Statview Version 4.0 (Abacus Concepts) was used for the analysis.

\section{RESULTS}

To determine the extent of the inhibitory capacity of normal RTS against IPNV, a dilution series was tested using 3 isolates of virus. Of these, 2 isolates, West Buxton and Buhl (both Serotype $\mathrm{A}_{1}$ ) were inhibited by at least $1 \log _{10} \mathrm{TCID}_{50} \mathrm{ml}^{-1}$ at dilutions of $1: 300$ and 1:1000, respectively. The Jasper isolate (Serotype $\mathrm{A}_{9}$ ) was inhibited at a dilution of 1:1000. Thus, to assure activity in all experiments, a 1:100 dilution of serum was used.

\section{Effect of RTS pretreatment of cells}

The average virus titers for wells treated with MEMRTS ranged from $10^{6.6}$ to $10^{7.0} \mathrm{TCID}_{50} \mathrm{ml}^{-1}$. These virus titers were not statistically different from the average virus titer of wells treated with MEM-10 $\left(10^{6.5}\right.$ TCID $_{50}$ $\left.\mathrm{ml}^{-1}\right)(\mathrm{p}=0.3818)$.

To determine if RTS inhibition was caused by the attachment of some serum component(s) to a cell receptor of the virus (thereby masking a viral receptor), cells were treated with varying amounts of RTS prior to viral infection. Regardless of RTS concentration, there was an approximately a 10-fold reduction in virus titer in wells containing RTS-treated cells, with average reductions of approximately $10^{-1} \mathrm{TCID}_{50} \mathrm{ml}^{-1}$. However, this level of reduction was not significantly different from that seen in the control wells that contained MEM-10-treated cells ( $p=0.3846$ ).

There were no significant differences in the levels of virus inhibition level between wells that received dif- 
ferent numbers of post-treatment washes. The average inhibition levels $\left(10^{-1} \mathrm{TCID}_{50} \mathrm{ml}^{-1}\right.$ reduction) from wells treated with MEM-RTS were not significantly different from the control MEM-10 ( $p=0.3846)$.

\section{Effect of time of serum addition on inhibition}

To determine the effect on virus inhibition of time of RTS addition to virus and cells, MEM-RTS was mixed with virus at different times before viral infection, or to host cells at different times after viral infection. The level of viral inhibition was dependent on the duration of the treatment with MEM-RTS (Fig. 1). The highest level of inhibition, a $10^{-6.3} \mathrm{TCID}_{50} \mathrm{ml}^{-1}$ reduction in virus titer, was obtained when the virus was treated with MEM-RTS $2 \mathrm{~h}$ before infection of cells. The inhibition level, however, was significantly decreased by $1 \mathrm{~h}$ pre-treatment, which resulted in $10^{-2.5} \mathrm{TCID}_{50} \mathrm{ml}^{-1}$ reduction in the virus titer, a level which was maintained for $16 \mathrm{~h}$ postinfection and was statistically significant $(p<0.05)$. The addition of MEM-RTS to the wells at 24 and $48 \mathrm{~h}$ post-infection had no significant effect on inhibition ( $p=0.0605)$.

\section{Effect of $2 \mathrm{~h}$ pre-infection treatment with RTS only vs. 7 d incubation with RTS}

To determine if the RTS inhibitor has a direct effect on IPNV, such as agglutination, virus titer was determined after a $2 \mathrm{~h}$ pre-treatment with MEMRTS or MEM-10. Pre-treatment with MEM-10 followed by incubation in MEM-10 for $7 \mathrm{~d}$ resulted in a virus titer of $10^{8} \mathrm{TCID}_{50} \mathrm{ml}^{-1}$. Pre-treatment of virus for $2 \mathrm{~h}$ with MEM-RTS, followed by dilution and incubation with MEM-10 for $7 \mathrm{~d}$, reduced the titer to $10^{-4.5}$ TCID $_{50} \mathrm{ml}^{-1}$. When MEM-RTS pre-treatment was combined with $7 \mathrm{~d}$ incubation in the presence of MEM-RTS, the titer was further reduced to $10^{-7.0} \mathrm{TCID}_{50} \mathrm{ml}^{-1}$ reduction.

\section{RTS and CHS inhibition of IPNV in RTG-2 and CHSE-214 cells}

To determine if serum inhibition of IPNV is related to serum source or to the species of host cell, we determined the cross-activity of inhibition in 2 cell lines, RTG-2 and CHSE214, using sera from 2 sources, RTS and CHS. Virus inhibition was cell-line dependent. IPNV was effectively inhibited $\left(10^{-3.0} \mathrm{TCID}_{50}\right.$ $\mathrm{ml}^{-1}$ reduction) by MEM-RTS when grown on the RTG-2 cell line. In the presence of MEM-RTS, no inhibition occurred for the CHSE-214 cells. On the other hand, MEM-CHS did not achieve such high inhibition as MEM-RTS. Although MEM-CHS inhibited viral replication more effectively in CHSE-214 cells than in RTG-2 cells $\left(10^{-0.8}\right.$ and $10^{-0.2}$ TCID $_{50} \mathrm{ml}^{-1}$ reduction, respectively), the inhibition level was not as high as that of MEM-RTS. However, the inhibition level $\left(10^{-0.8} \mathrm{TCID}_{50} \mathrm{ml}^{-1}\right.$ reduction) was statistically different from that in the control wells $(p=0.0194)$.

In terms of CPE level, until the 4th day both MEMRTS and MEM-CHS showed a similar level of CPE (Level 0) in RTG-2 cells, while MEM-10, positive control, showed a CPE (Level 1) 2 d after viral infection (data not shown). However, after the 4 th day, the CPE level in MEM-CHS rapidly increased to the same level of CPE (Level 4) and the virus titer of the positive control (MEM-10).

\section{Sensitivity of virus to RTS following passage through RTG-2 or CHSE-214 cells}

We determined the change in RTS sensitivity as a function of the host cells in which the virus was replicated, and found that this can be significantly affected by the cell line in which virus is produced (Table 3). There was no significant difference in the RTS inhibition level of the IPNV isolate Thailand after 1 passage through the CHSE-214 or RTG-2 cell lines $(p=0.8147)$. In both of these cell lines, RTS inhi-

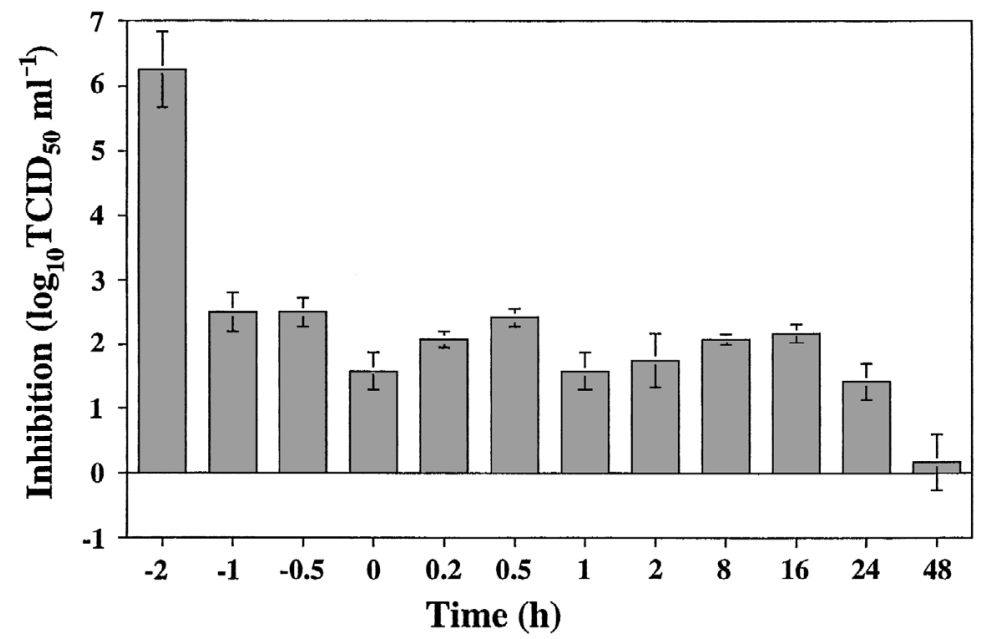

Fig. 1. Time-dependence (mean $\pm \mathrm{SE}$ of 3 replicates) of rainbow trout serum (RTS) inhibitory activity against infectious pancreatic necrosis virus (IPNV). Medium with rainbow trout serum (MEM-RTS) was added to IPNV-Jasper prior to exposure of cells (negative times), concurrent with addition of viurs (time, $t=0$ ), and at various times after addition of virus to rainbow trout gonad (RTG)-2 cells. Inhibitory activity of RTS was measured at $7 \mathrm{~d}$ post-exposure 
Table 3. Change in RTS sensitivity after passage IPNV-Thailand through 2 different cell lines, RTG-2 or CHSE-214. IPNV-Thailand was passaged 5 times through CHSE-214 or RTG-2 cells. RTS sensitivity was compared for Passages 1 and 5 in either CHSE (CHSE-214) or RTG (RTG-2). After $2 \mathrm{~h}$ incubation with MEM-10 or MEM-RTS, inactivation of each passaged virus was measured to determine change in RTS inhibition. Inhibition $>10^{1.0}$ considered significant. Values are $\log _{10} \mathrm{TCID}_{50} \mathrm{ml}^{-1}$ )

\begin{tabular}{|lccc|}
\hline \multirow{2}{*}{ Virus passage } & \multicolumn{2}{c|}{ Virus titer in } & Inhibition \\
& MEM & RTS & level \\
\hline CHSE & & & \\
Passage 1 & 9.5 & 6.1 & $3.4 \pm 0.3$ \\
Passage 5 & 8.3 & 6.4 & $1.9 \pm 0.3$ \\
RTG & & & \\
Passage 1 & 9.3 & 6.0 & $3.3 \pm 0.3$ \\
Passage 5 & 6.4 & 3.5 & $2.9 \pm 0.3$ \\
\hline
\end{tabular}

bition levels resulted in an approximately $10^{-3.4} \mathrm{ml}^{-1}$ $\mathrm{TCID}_{50}$ reduction. However, 5 viral passages in CHSE-214, significantly affected RTS sensitivity, resulting in a reduction of only $10^{-1.9} \mathrm{TCID}_{50} \mathrm{ml}^{-1}(\mathrm{p}=$ 0.0104). The sensitivity of IPNV Thailand passed through RTG-2 was not significantly affected $\left(10^{0.4}\right.$ TCID $_{50} \mathrm{ml}^{-1}$ difference in RTS inhibition level) between Passages 1 and $5(p=0.3650)$.

\section{Effect of cell density on RTS inhibition}

RTS inhibition was tested at different densities of RTG-2 cells to determine if RTS inhibition is dependent on the cell density at which RTS inhibition is tested. RTS inhibition was highly dependent on the confluency levels of the cell monolayer at the time of viral infection (Fig. 2). The confluence levels of the cell monolayer tested varied from 70 to $100 \%$ confluency: $70 \%$ confluency (at approx. $1 \times 10^{5}$ cells ml $^{-1}, 80 \%$ at approx. $1.2 \times 10^{5}$ cells $\mathrm{ml}^{-1}$ ), loosely $100 \%$ at approx. $2 \times 10^{5}$ cells ml ${ }^{-1}$ ), tightly $100 \%$ at approx. $3 \times 10^{5}$ and $8 \times 10^{5}$ cells $\mathrm{ml}^{-1}$ ). The inhibition level ranged from no significant inhibition at a cell density of $\leq 2 \times 10^{5} \mathrm{ml}^{-1}$ to $10^{-6.5} \mathrm{TCID}_{50} \mathrm{ml}^{-1}$ reduction in virus titer at a cell density of $8 \times 10^{5} \mathrm{ml}^{-1}$. Below a cell density of $2 \times 10^{5} \mathrm{ml}^{-1}$, the inhibition level was insignificant, with a maximum recorded inhibition of $10^{-1.1} \mathrm{TCID}_{50} \mathrm{ml}^{-1}$. Although inhibition at $1.2 \times 10^{5}$ cells ml ${ }^{-1}$ was $10^{-1.1} \mathrm{TCID}_{50} \mathrm{ml}^{-1}$, this was not statistically significant from that of the control ( $p=0.1379)$. At the highest cell densities, inhibition levels were $10^{-6.3} \mathrm{TCID}_{50} \mathrm{ml}^{-1}$ reduction at $3 \times$ $10^{5}$ cells ml ${ }^{-1}$ and $10^{-6.5} \mathrm{TCID}_{50} \mathrm{ml}^{-1}$ reduction at $8 \times 10^{5}$ cells $\mathrm{ml}^{-1}$. These levels of reduction were significantly higher those for the lower cell densities at $3 \times 10^{5}$ cells $\mathrm{ml}^{-1}(\mathrm{p}<0.0001)$ and $8 \times 10^{5}$ cells ml $^{-1}(\mathrm{p}=0.0003)$.

\section{Virus inhibition in salmonid and non-salmonid cell lines}

We tested 9 salmonid and 4 non-salmonid cell lines to determine if virus inhibition of RTS inhibitor was cell-line specific, and found that serum inhibition was host-cell specific, with RTS (salmonid serum) showing a higher inhibition when the virus was incubated in salmonid cell lines rather than in non-salmonid cell lines. Of the 9 salmonid cell lines tested, strong RTS inhibition was found in 5: RTG-2 $\left(10^{-6.6} \mathrm{TCID}_{50} \mathrm{ml}^{-1}\right)$, RTH-149 $\left(10^{-6.6}\right.$ TCID $\left._{50} \mathrm{ml}^{-1}\right)$, STE-137 $\left(10^{-6.1}\right.$ TCID $_{50}$ $\left.\mathrm{ml}^{-1}\right)$, YNK $\left(10^{-6.0} \mathrm{TCID}_{50} \mathrm{ml}^{-1}\right), \mathrm{CHH}-1\left(10^{-6.0} \mathrm{TCID}_{50}\right.$ $\mathrm{ml}^{-1}$ reduction) (Fig. 3). No inhibition of virus $\left(<10^{-0.1}\right.$ TCID $_{50} \mathrm{ml}^{-1}$ reduction) was evident in the other salmonid cell lines (KO-6, SSE-5, CHSE-214 and CHSE-114). Among the salmonid cell lines, the highest level of inhibition was in host cells from the homologous species (RTG-2 and RTH-149 cells) (Fig. 3). Of the 4 non-salmonid cell lines tested, 2 (BF-2 and PHE-184) did not show significant RTS inhibition $\left(<10^{-1.0}\right.$ TCID $_{50}$ $\mathrm{ml}^{-1}$ reduction) (Fig. 4). The 2 ictalurid cell lines (CCO and $\mathrm{BB}$ ) tested showed significant virus inhibition: $10^{-1.9} \mathrm{TCID}_{50} \mathrm{ml}^{-1}(\mathrm{p}<0.0001)$ and $10^{-3.8} \mathrm{TCID}_{50} \mathrm{ml}^{-1}$ reduction ( $p=0.0002)$, respectively. However, their level of RTS inhibition was significantly lower than the levels with the 5 salmonid cell lines that showed signif-

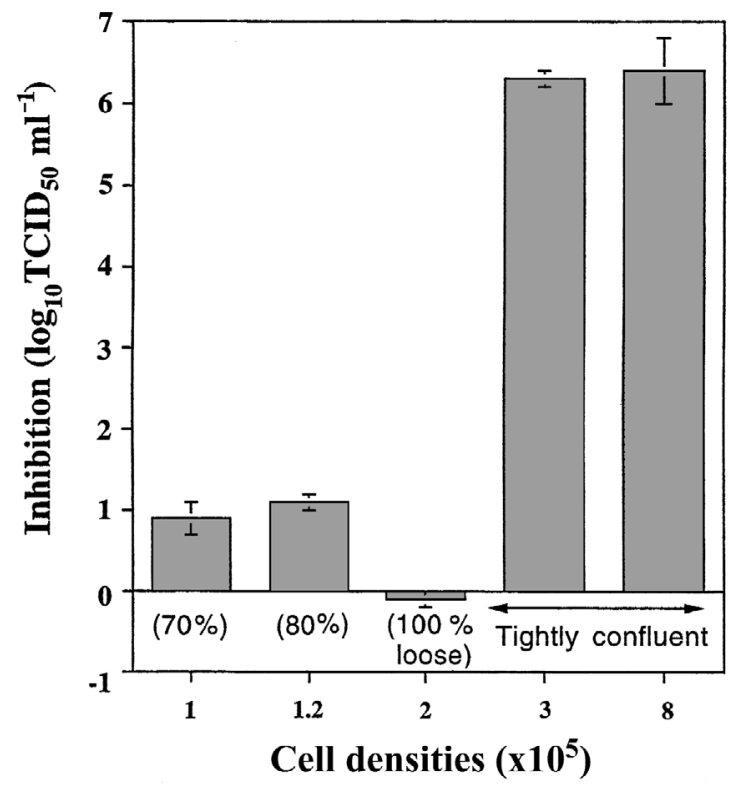

Fig. 2. Effect (mean \pm SE of 3 replicates) of RTG-2 cell density on RTS inhibitory activity. Confluency of cell monolayer at each cell density was $70 \%$ confluency at $1 \times 10^{5} \mathrm{cells} \mathrm{ml}^{-1}$, $80 \%$ at $1.2 \times 10^{5} \mathrm{ml}^{-1}$, loosely $100 \%$ at $2 \times 10^{5} \mathrm{ml}^{-1}$, tightly $100 \%$ at $3 \times 10^{5} \mathrm{ml}^{-1}$, and at $8 \times 10^{5} \mathrm{ml}^{-1}$. Virus inhibition tested at each cell density with IPNV-Jasper. Inhibition of virus titer was measured $7 \mathrm{~d}$ post-exposure 


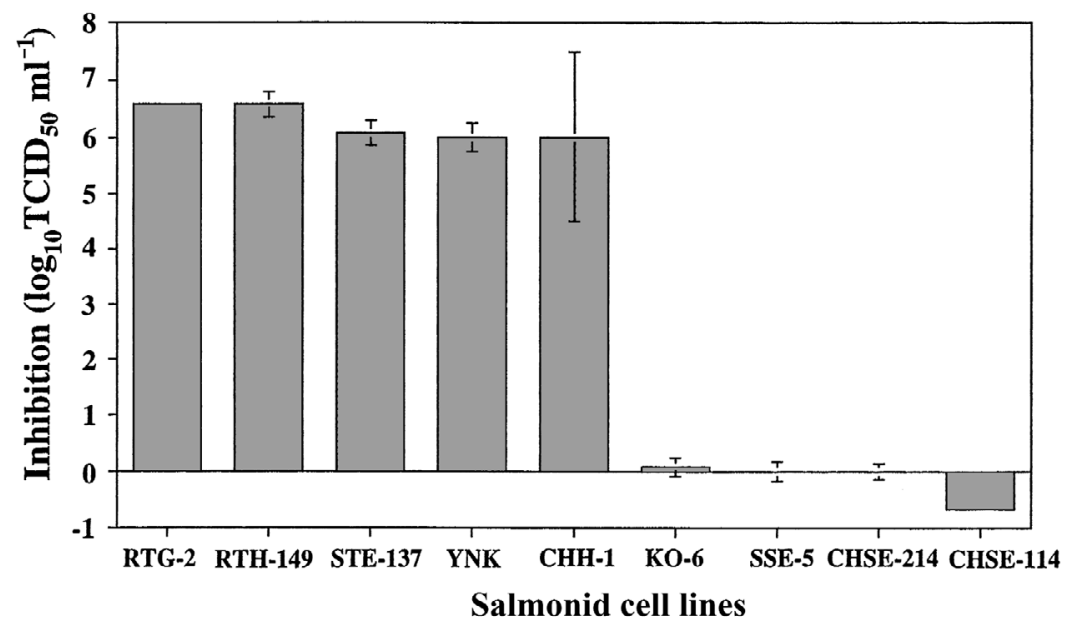

Fig. 3. Inhibition (mean $\pm \mathrm{SE}$ of 3 replicates) of IPNV-Jasper by RTS in salmonid cell lines. Virus inhibition measured $7 \mathrm{~d}$ post-exposure in 9 salmonid cell lines: RTG-2 (rainbow trout gonad-2); RTH-149 (rainbow trout heart-149); STE-137 (steelhead salmon embryo-137); YNK (yamame kidney); CHH-1 (chum heart-1); KO-6 (kokanee ovary-6); SSE-5 (sockeye salmon embryo-5); CHSE-214 (chinook salmon embryo-214); CHSE-114 (chinook salmon embryo-114)

icant inhibition $(\mathrm{p}=0.0014)$. Virus inhibition was not dependent on cell morphology, epithelioid or fibroblastic.

\section{Interspecific range of serum inhibitory activity directed against IPNV}

The inhibition activity of sera obtained from 7 species of fishes was tested to determine the interspecific range of virus inhibition of 2 isolates known to be sensitive to RTS (see Table 1 for list of species and abbreviations). Inhibition activity showed high variation depending on serum sources and virus tested. No significant serum inhibition of IPNV-Thailand was found in 3 non-salmonid sera-flounder (FLS), sablefish (SAS), and herring. All 4 salmonid sera inhibited IPNV-Thailand, while no inhibition was detected for non-salmonid sera. Except for BTS, the salmonid sera tested produced high inhibition, while non-salmonid serum did not inhibit virus replication.

The Thailand isolate was only slightly inhibited by BTS $\left(10^{-1.5}\right.$ TCID $_{50} \mathrm{ml}^{-1}$ titer reduction); however, the inhibition level was statistically different from that of the controls $(p=0.0056)$. IPNV isolate Jasper was less inhibited by salmonid sera than the IPNV Thailand isolate. IPNV-Jasper was inhibited by RTS and COS $\left(10^{-6.5}\right.$ and $10^{-2.2} \mathrm{TCID}_{50} \mathrm{ml}^{-1}$ reduction, respectively) however, the isolate was not significantly inhibited by CHS $\left(10^{0} \mathrm{TCID}_{50} \mathrm{ml}^{-1}\right.$ reduction) or brook trout serum (BTS) $\left(10^{-0.6} \mathrm{TCID}_{50} \mathrm{ml}^{-1}\right.$ reduction) $(\mathrm{p}=0.5072)$.

\section{DISCUSSION}

Previous work has indicated that there is significant variation in RTS inhibition levels depending upon the IPNV isolate used (Ögüt 1995). There is little information on the effects of virus passage history, cell line, cell density or other factors that may be encountered during in vitro studies on RTS inhibition. The experiments we conducted were designed to determine whether any of these factors could affect the ability of RTS to inhibit IPNV replication. Ögüt (1995) found that each IPNV isolate has a different sensitivity to RTS. In this study we also found significant differences in sensitivity to RTS, depending on the cell type or conditions used when assaying for inhibition. Hill \& Dixon (1977) reported that sensitivity to RTS was developed sooner for IPNV that was serially passed through the EPC cyprinid line than in RTG-2 or BF cell lines. Kelly \& Nielsen (1985) reported that susceptibility of IPNV-VR 299 from 2 separate laboratories to RTS was different; the virus from one laboratory was inhibited, but the virus from the other laboratory was not. We also found that sensitivity changed, depending on the cells in which the virus was replicated. Although Kelly \& Nielsen (1985) reported RTS inhibition in CHSE-214, we found that although this virus was sen-

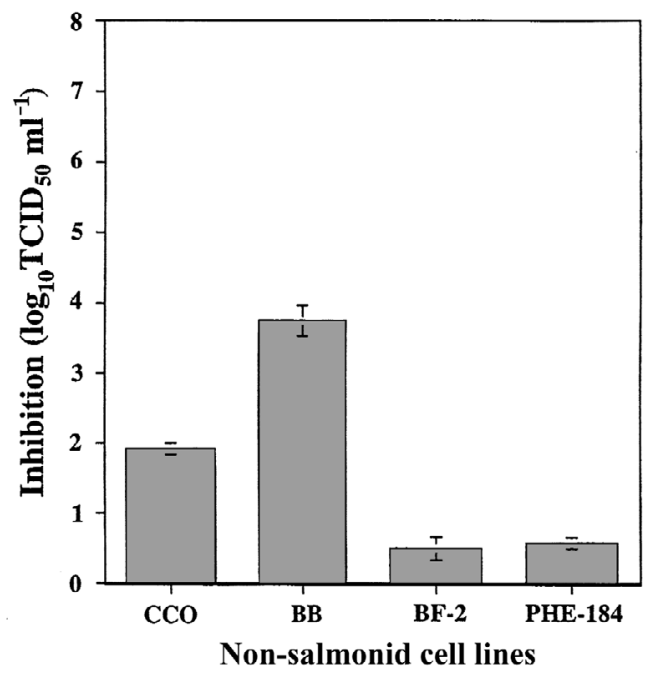

Fig. 4. Inhibition activity (mean $\pm \mathrm{SE}$ of 3 replicates) directed against IPNV-Jasper in non-salmonid cell lines. Virus inhibition of RTS inhibitor measured $7 \mathrm{~d}$ postexposure in 4 nonsalmonid cell lines: CCO (channel catfish ovary); BB (brown bullhead); BF-2 (bluegill sunfish-2); PHE-184 (Pacific herring embryo-184) 
sitive to RTS when grown in RTG-2 cells, there was no evidence of inhibition in CHSE-214 cells over a period of $7 \mathrm{~d}$ incubation. However, an RTS-sensitive virus that had replicated in RTG-2 cells became less sensitive to RTS when passed 5 times through CHSE cells. IPNV begins to produce large numbers of progeny after at least $20 \mathrm{~h}$ (Malsberger \& Cerini 1963), and it is possible that the virus raised in the CHSE-214 cell line is resistant to the RTS inhibitor, or that interferon production in CHSE-214 is not high enough to inhibit IPNV replication. Our suggestion of interferon involvement is based upon our observation of different levels of virus inhibition in cell lines from salmonids and nonsalmonids. Furthermore, RTS inhibition was high at high cell densities, when higher levels of interferon production would be expected. Both the RTG-2 and CHSE-214 cell lines have been known to become persistently infected by defective interfering particles (MacDonald \& Kennedy 1979, Hedrick \& Fryer 1981). The RTG-2 (Okamoto et al. 1983b) and CHSE-214 (Jensen et al. 2002) cell lines, and rainbow trout (de Kinkelin \& Dorson 1973) have been known to produce interferon-like activity. The result of our experiment on the effect of RTS pretreatment of cells for $24 \mathrm{~h}$ before infection indicates that inhibition is not induced by pretreatment of RTG-2 cells with RTS, such as interferon. Another result of our experiments confirmed that RTS inhibition was not related to the masking of viral receptors on the cells. However, an interesting result was obtained from our experiment on the effect of cell density on RTS inhibition (Fig. 2), whereby higher cell densities yielded higher inhibition by RTS. This result indicated 2 possible mechanisms: (1) interferon involvement, since interferon inhibition was stronger when RTG-2 cell density was high (Okamoto et al. 1983b); (2) the progeny virus replicated at high cell density may be more sensitive to RTS. However, we found no significant difference in RTS sensitivity between virus produced in low and high cell densities of RTG-2 cells (data not shown). It has been reported that IPNV induced interferon in both rainbow trout (Dorson et al. 1992) and in cell lines from rainbow trout (De Sena \& Rio 1975, Okamoto et al. 1983b). Fathead minnow cells (FHM) (Gravell \& Malsberger 1965, Oie \& Loh 1971) and RTG-2 cells (Okamoto et al. 1983b) have been well studied in this respect, and have been shown to secrete interferon in response to viral infection. Interestingly these 2 cell lines, FHM and RTG-2, have been most often used in virus inhibition tests in vitro. Okamoto et al. (1983b) reported that inteferon production due to IPNV infection in RTG-2 cells was dependent on cell densities; interferon production was high for tightly confluent cell monolayers and low for loosely confluent cell monolayers. They also found that viral infectivity titers were notably decreased for a tightly confluent $3 \mathrm{~d}$ old cell monolayer. They interpreted the low viral infectivity titer as a consequence of high interferon production. In our study, inhibition by RTS was high for a tightly confluent cell monolayer while there was no inhibition for a loosely confluent cell monolayer.

Neither RTG-2 nor CHSE-214 cells showed CPE until $3 \mathrm{~d}$ after exposure to IPNV (data not shown). However, after 3 d later, CPE rapidly appeared in CHSE-214, and ultimately these cells produced the same virus titer in MEM-10 and 1\% RTS as in MEM10. In contrast, virus grown in RTG-2 cells in the presence of $1 \%$ RTS showed no evidence of CPE.

In general, CPE development in RTG-2 was dependent on serum source and cell density. At a low cell density (approx. 1 to $2 \times 10^{5}$ cells ml $^{-1}$ ), CPE developed in 5 to $7 \mathrm{~d}$, while at a high cell density (approx. 3 to $8 \times$ $10^{5}$ cells $\mathrm{ml}^{-1}$ ), CPE was not apparent even at 7 and $14 \mathrm{~d}$ post infection. However, CPE development did not always follow this pattern, being dependent on serum source and the freshness of the RTS. Chinook salmon serum did not significantly inhibit IPNV replication in CHSE-214 or RTG-2 cells; however, we found that higher inhibition was obtained for CHSE-214 cells than for RTG-2 cells. This indicates that the lack of inhibition by RTS in CHSE-214 is partially related to serum-host specificity as well as to cell line.

As reported by Dorson et al. (1975), we found that sensitivity of IPNV to RTS changes with the number of passages through a particular cell line. There was no difference in the sensitivity of the virus to RTS in the cell lines RTG-2 and CHSE-214 at the first exposure to RTS before viral attachment to the cell. However, after 5 passages through these cells, the virus produced in CHSE-214 cells eventually become more RTS-resistant. This result led us to consider whether RTG-2 and CHSE-214 cells may have different cell-membrane characteristics that could cause IPNV to undergo viral modification such as seen in the enveloped virus. The possibility of glycosylation in Capsid Protein VP2 of IPNV has been suggested (Estay et al. 1990, Hávarstein et al. 1990, Hjalmarsson et al. 1999) and may consequently have an effect on RTS sensitivity. The question as to whether this occurs in certain cells remains open.

Inhibition of IPNV by RTS has been reported in nonsalmonid cell lines, FHM (Kelly \& Nielsen 1985), BF-2 and EPC (Hill \& Dixon 1977). The toxicity of RTS to EPC cells has also been reported by Hattenberger et al. (1989). In our study we found that RTS was toxic to the FHM and EPC cell lines even at 1:1000 RTS dilution. We also found that RTS inhibition was insignificant in BF-2 and PHE-184 cells. However, we found significant RTS inhibition for CCO and BB cell lines. The difference between our results on RTS inhibition in BF-2 cells and those of Hill \& Dixon (1977) may be 
the result of differences in the methods used. Hill \& Dixon (1977) used a plaque assay method with approximately 2 to $4 \mathrm{~d}$ incubation, while our experiments involved $7 \mathrm{~d}$ incubation. As in the inhibition comparison between RTG-2 and CHSE-214, we suspect that IPNV in BF-2 cells may have initially been inhibited by RTS, but that the virus was not inhibited further during the subsequent $7 \mathrm{~d}$ incubation.

All data on serum inhibition of IPNV has been obtained using rainbow trout serum (VestergardJörgensen 1973, Dorson \& de Kinkelin 1974, Hill \& Dixon 1977, Dorson et al. 1978, Kelly \& Nielsen 1985, Ögüt 1995). In our study serum inhibition of IPNV occurred only when salmonid sera was used. Nonsalmonid sera had no inhibitory effects on IPNV. Of the 4 salmonid sera tested, 3 showed strong inhibition of both strains of IPNV. BTS, however, showed only slight inhibition of IPNV-Thailand and no inhibition of IPNVJasper. This result has biological significance, as brook trout are known to be the species most susceptible to IPNV (Silim \& Lagace 1982). It is possible that serum inhibitor (' $6 \mathrm{~S}^{\prime}$ ) is present only in salmonid sera. It is also possible that different species of salmon have different amounts of serum inhibitor. In these experiments we used the salmonid cell line RTG-2, and the lack of inhibition seen with non-salmonid sera may have been caused by our use of this particular salmonid cell line. Although we cannot rule out this possibility, we do not feel that it is necessarily the case, since herring serum did not inhibit IPNV-Jasper in the herring cell line PHE-184 (data not shown).

Kelly \& Nielsen (1985) determined the effect of trout serum on ${ }^{32} \mathrm{P}$-labeled IPNV-Sp adsorption. They observed that approximately $97 \%$ of IPNV-Sp was not adsorbed to the FHM cells in the presence of RTS, whereas about $55 \%$ of the control virus was not adsorbed to the cells. In our experiment on the effect of $2 \mathrm{~h}$ pretreatment with RTS we found that IPNV was strongly inactivated by only a $2 \mathrm{~h}$ treatment with RTS and was even more inactivated when RTS was present in the media during a $7 \mathrm{~d}$ incubation period of viral replication. Even though our experiment and the experiment of Kelly \& Nielsen (1985) were conducted by different methods, both studies observed that IPNV is directly inhibited by RTS and that some portion of the virus could be adsorbed to cells even in the presence of RTS. We found that RTS needs to be present during viral replication to inhibit the replication of penetrated virus. Future studies of RTS inhibition using a $7 \mathrm{~d}$ incubation period will concentrate more on the cell line used than on serum-host cell-specificity. Phenotypic characteristics of progeny virus and the amount of interferon production by cells could be important factors for RTS inhibition during the $7 \mathrm{~d}$ incubation period.
In conclusion, this study has shown that RTS directly inhibits IPNV and that the RTS inhibition level is dependent on many factors: time at which the virus is exposed to RTS, serum source, host-cell characteristics, and virus-passage history. Salmonid sera have a higher inhibition activity than non-salmonid sera.

Acknowledgements. We would like to thank the people in the Fish Disease Laboratory of Oregon Department of Fish and Wildlife for their kind support. The authors thank Dr. Stewart Johnson at the Institute for Marine Biosciences for his review of the manuscript. This research was funded by National Sea Grant NOAA88-204 and supported by the Mamie Markham Fund.

\section{LITERATURE CITED}

Bowser PR (1976) Fluorescent antibody test for channel catfish virus. Fish Health News 5(4):4-5

Caswell-Reno P, Reno PW, Nicholson BL (1986) Monoclonal antibodies to infectious pancreatic necrosis virus: analysis of viral epitopes and comparison of different isolates. J Gen Virol 67:2193-2205

Caswell-Reno P, Lipipun V, Reno PW, Nicholson BL (1989) Use of a group reactive and other monoclonal antibodies in an enzyme immunodot assay for identification and presumptive serotyping of aquatic birnaviruses. J Clin Microbiol 27:1924-1929

de Kinkelin P, Dorson M (1973) Interferon production in rainbow trout (Salmo gairdneri, Richardson) experimentally infected with Egtved virus. J Gen Virol 19:125-127

de Kinkelin P, Le Berre M (1974) Nécrose hématopoïétique infectieuse des salmonidés:production d'interféron circulant induite après 1'infection expérimentale de la truite arc-en-ciel (Salmo gairdneri, Richardson). C R Hebd Séances Acad Sci Sér D 279:445-448

De Sena J, Rio GJ (1975) Partial purification and characterization of RTG-2 fish cell interferon. Infect Immun 11: 815-822

Dorson M, de Kinkelin P (1974) Nécrose pancréatique infectieuse des salmonidés: existence dans le sérum de truites indemnes d'une molécule $6 \mathrm{~S}$ neutralisant spécifiquement le virus. C R Hebd Séances Acad Sci Sér D 278:785-788

Dorson M, de Kinkelin P, Torchy C (1975) Virus de la nécrose pancréatique infectieuse: acquisition de la sensibilité au facteur neutralisant du serum de truite après passages successifs en culture cellulaire. C R Hebd Séances Acad Sci Sér D 281:1435-1438

Dorson M, Castric J, Torchy C (1978) Infectious pancreatic necrosis virus of salmonids: biological and antigenic features of a pathogenic strain and a non-pathogenic variant selected in RTG-2 cells. J Fish Dis 1:309-320

Dorson M, de Kinkelin P, Torchy C (1992) Interferon synthesis in rainbow trout fry following infection with infectious pancreatic necrosis virus. Fish Shellfish Immunol 2: 311-313

Estay A, Farias G, Soler M, Kuznar J (1990) Further analysis on the structural proteins of infectious pancreatic necrosis virus. Virus Res 15:85-96

Gravell M, Malsberger RG (1965) A permanent cell line from the fathead minnow (Pimephales promelas). Ann NY Acad Sci 555-565

Hattenberger-Baudouy AM, Danton M, Merle G (1989) Serological evidence of infectious hematopoietic necrosis in 
rainbow trout from a French outbreak of disease. J Aquat Anim Health 1:338-347

Hávarstein LS, Kalland KH, Christie KE, Endersen C (1990) Sequence of the large double-stranded RNA segment of the N1 strain of infectious pancreatic necrosis virus: a comparison with other Birnaviridae. J Gen Virol 71: 299-308

Hedrick RP, Fryer JL (1981) Persistent infection of three salmonid cell lines with infectious pancreatic necrosis virus (IPNV). Fish Pathol 15:163-172

Hill BJ (1982) Infectious pancreatic necrosis virus and its virulence. In: Roberts RJ (ed) Microbial diseases of fish. Academic Press, London, p 91-114

Hill BJ, Dixon PF (1977) Studies on IPN virulence and immunization. Bull Off Int Epizoot 87:425-427

Hjalmarsson A, Carlemalm E, Everitt E (1999) Infectious pancreatic necrosis virus: identification of a VP3-containing ribonucleoprotein core structure and evidence for Olinked glycosylation of the capsid protein VP2. J Virol 73: 3484-3490

Jensen I, Larsen R, Robertsen B (2002) An antiviral state induced in Chinook salmon embryo cells (CHSE-214) by transfection with the double-stranded RNA poly I:C. Fish Shellfish Immunol 13:367-378

Kelly RK, Nielsen O (1985) Inhibition of infectious pancreatic necrosis virus by serum from normal rainbow trout (Salmo gairdneri) in Canadian hatcheries. Fish Pathol 19:245-251

Lannan CN, Winton JR, Fryer JR (1984) Fish cell lines: establishment and characterization of nine cell lines from salmonids. In Vitro 20:671-676

Macdonald RD, Gower DA (1981) Genomic and phenotypic divergence among three serotypes of aquatic birnaviruses (infectious pancreatic necrosis virus). Virology 114: 187-195

Macdonald RD, Kennedy JC (1979) Infectious pancreatic virus persistently infects chinook salmon embryo cells independent of interferon. Virology 95:260-264

Malsberger RG, Cerini CP (1963) Characteristics of infectious pancreatic necrosis virus. J Bacteriol 86:1283-1287

Ögüt H (1995) In vitro host range of aquatic birnaviruses and their relationship to virulence. MSc thesis, Oregon State University, Newport, OR

Editorial responsibility: Jo-Ann Leong,

Kaneohe, Hawaii, USA
Oie HK, Loh PC (1971) Reovirus type 2: induction of viral resistance and interferon production in fathead minnow cells. Proc Soc Exp Biol Med 136:369-373

Okamoto N, Sano T, Hedrick RP, Fryer JL (1983a) Antigenic relationships of selected strains of infectious pancreatic necrosis virus and European eel virus. J Fish Dis 6: $19-25$

Okamoto N, Shirakura T, Nagakura Y, Sono T (1983b) The mechanism of interference with fish viral infection in the RTG-2 cell line. Fish Pathol 18:7-12

Reno PW (1999) Infectious pancreatic necrosis and associated aquatic birnaviruses. In: Woo PTK, Bruno DW (eds) Fish diseases and disorders, Vol 3. Viral, bacterial and fungal infections. CAB International, New York, p 1-55

Silim A, Lagace Y (1982) Susceptibility of trouts of different species and origins to various isolates of infectious pancreatic necrosis virus. Can J Fish Aquat Sci 39:1580-1584

Spearman C (1908) The method of 'right and wrong cases' (constant stimuli) without Gauss's formulae. Br J Psychol $2: 227-234$

Vestergard-Jörgensen PE (1973) The nature and biological activity of IPN virus neutralizing antibodies in normal and immunized rainbow trout (Salmo gairdneri). Arch Ges Virusforsch 42:9-20

Watanabe T, Kobayashi N, Sato Y, Ishizaki Y (1978) Continuous cell line derived from the kidney of yamame, Oncorhynchus masou. Bull Jpn Soc Sci Fish 44:415-418

Wattanavijarn W, Torchy C, Tangtrongpiros J, de Kinkelin P (1988) Isolation of a birnavirus belonging to the Sp serotype, from southeast Asia fisheries. Bull Eur Assoc Fish Pathol 8:106-108

Wolf K, Quimby MC (1962) Established eurythermic cell line of fish cell in vitro. Science 135:1065-1066

Wolf K, Quimby MC (1966) Lymphocystis virus: isolation and propagation in centrarchid fish cell lines. Science 151: 1004-1005

Wolf K, Quimby MC (1969) Fish cell and tissue culture. In: Hoar WS, Randall DJ (eds) Fish physiology. Academic Press, New York, p 253-305

Yamamoto $\mathrm{T}$ (1974) Infectious pancreatic necrosis virus occurrence at a hatchery in Alberta. J Fish Res Board Can $31: 397-402$

Submitted: February 25, 2003; Accepted: June 3, 2004

Proofs received from author(s): November 25, 2004 